\title{
Orbitotomía lateral mediante abordaje temporal
}

\section{Lateral orbitotomy using a temporal approach}

\author{
H. Herencia Nieto5, J.J. Verdaguer Martín1, F. Riba García², J. Calvo de Mora Álvarez', \\ A. del Amo Fernández de Velasco5, R. Pujol Romanya3 , C. Navarro Cuéllar ${ }^{4}$
}

Resumen: La orbitotomía lateral sigue siendo en el momento actual la técnica quirúrgica de elección para la biopsia o extirpación de lesiones intraorbitarias laterales al nervio óptico, la biopsia del propio nervio óptico y la extirpación de la glándula lacrimal.

Se han descrito múltiples incisiones cutáneas para llevar a cabo esta intervención; la más frecuentemente empleada por el momento es la incisión palpebral, que discurre a nivel de alguna arruga del párpado superior. Aunque los resultados obtenidos con esta incisión suelen ser aceptables, no está exenta de complicaciones, ni estéticas ni funcionales.

Por esto, en los últimos años han ido apareciendo nuevas incisiones que intentan evitar estas complicaciones. Entre estas nuevas vías de abordaje a la pared lateral de la órbita se encuentra la incisión temporal.

En los últimos 3 años, se ha intervenido en nuestro servicio a cuatro pacientes para llevar a cabo biopsia o extirpación de masas intraorbitarias mediante orbitotomía lateral, siempre a través de una incisión temporal. En todos los casos esta incisión permitió una amplia exposición del campo quirúrgico y la cómoda realización de la intervención, obteniéndose resultados estéticos y funcionales excelentes, y sin ninguna secuela ni complicación permanente.

La complicación específica más frecuente de esta incisión es la paresia de la rama frontal del nervio facial. Una técnica de disección cuidadosa suele ser suficiente para evitarla.

Todo esto hace que esta incisión, tal y como la describimos aquí, sea de elección para llevar a cabo la orbitotomía lateral, constituyendo en nuestro criterio una alternativa perfectamente válida y a tener en cuenta frente a las incisiones «clásicas», a las que llega a superar en muchos aspectos.

Palabras clave: Órbita; Tumor de órbita; Cirugía de órbita; Orbitotomía lateral.

Recibido: 5.07.05

Aceptado: 15.11 .05

1 Médico Adjunto. Servicio de Cirugía Oral y Maxilofacial. Hospital General Universitario Gregorio Marañón, Madrid.

2 Médico Adjunto. Servicio de Cirugía Oral y Maxilofacial. Complejo Hospitalario de Ciudad Real.

3 Médico Adjunto. Servicio de Cirugía Oral y Maxilofacial. Hospital Virgen de la Salud, Toledo.

4 Médico Adjunto. Servicio de Cirugía Oral y Maxilofacial. Hospital Universitario de Guadalajara.

5 Médico Residente. Servicio de Cirugía Oral y Maxilofacial. Hospital General Universitario Gregorio Marañón, Madrid, España.

\section{Correspondencia:}

Honorio Herencia Nieto.

Calle Jose Domingo Rus, nำ23 11ㅜ escalera derecha. 28043. Madrid, España.

e-mail: jonor@excite.com
Abstract: The lateral orbitotomy it still the surgical technique of choice for biopsies or the removal of intraorbital lesions that are lateral to the optic nerve, for biopsies of the optic nerve itself and for removing the lacrimal gland.

Many skin incisions have been described for carrying out this surgical procedure, the most common at this moment being the upper eyelid crease incision. Although the results obtained with this incision tend to be acceptable, they are not exempt of complications, either aesthetic or functional.

Over the last years new incisions have appeared that try to avoid these complications. Among the new approach routes to the lateral wall of the orbit is the temporal incision.

Over the last three years four patients have undergone surgical procedures in order to carry out biopsies or for the removal of intraorbital masses by means of an incision into the temple. In all cases the incision permitted ample exposure of the surgical field and performing the procedure with ease. Excellent aesthetic and functional results were obtained with no sequelae or permanent complications.

The most common complication that is specific to this incision is paresthesia of the frontal branch of the facial nerve. A careful dissection technique tends to be sufficient for avoiding this.

In our view this incision, as we describe it, is the incision of choice for carrying out a lateral orbitotomy and we conclude that in our view it is a perfectly valid technique and one that should be considered with regard to the «classical» incisions, as in many aspects it surpasses these.

Key words: Orbit; Tumor of the orbit; Orbital surgery; Lateral orbitotomy. 


\section{Introducción}

La órbita y su contenido constituyen una entidad anatómicamente compleja. La existencia de determinadas patologías a este nivel obliga en ocasiones al tratamiento quirúrgico de las mismas (biopsia o extirpación de tumores, descompresión quirúrgica en la enfermedad de Graves-Basedow, etc.). La elección de la adecuada vía de abordaje, en función al tipo de patología y a su localización dentro de la órbita, es fundamental para asegurar el éxito del procedimiento., 1,2

Hasta el momento, la orbitotomía lateral, se considera la técnica ideal para el acceso a lesiones de la mitad lateral de la órbita, la biopsia del nervio óptico y la extirpación de la glándula lacrimal.1,3,4

Clásicamente, para alcanzar la pared lateral de la órbita, las incisiones cutáneas se han planificado en la región cantal externa o en la palpebral superior. Dichas incisiones han sufrido múltiples modificaciones desde la primera descripción de esta intervención por Krönlein en 1888 hasta nuestros días (Fig. 1). La incisión original de Krönlein tiene un trayecto curvilíneo de convexidad anterior en la zona del reborde orbitario lateral. En 1960, Stallard y Wright popularizaron su incisión en forma de «s» itálica, con un trayecto paralelo al reborde orbitario externo desde la cola de la ceja y un trazo final paralelo al arco zigomático. Esta vía de abordaje ha sido ampliamente utilizada por la mayoría de los cirujanos hasta la aparición de la incisión palpebral. Ésta es una modificación de la de Stallard-Wright, pero que discurre por un pliegue del párpado superior, y ha desplazado a su predecesora, siendo considerada en el momento actual por muchos autores la incisión de elección para la orbitotomía lateral. ${ }^{5}$

Aunque los resultados obtenidos con esta incisión pueden considerarse satisfactorios en la mayoría de los casos, no está exenta de potenciales complicaciones como cicatrices visibles, lesión del músculo elevador del párpado y retracción palpebral. ${ }^{6}$

Con el fin de evitar estas complicaciones, en los últimos tiempos, diferentes vías de abordaje utilizadas en cirugía craneofacial se han propuesto para llevar a cabo la orbitotomía lateral, 7 pudiendo destacar como más importantes el abordaje coronal, 7,8 el temporozigomático ${ }^{9}$ y el empleado en la orbitotomía postero-lateral, a través de una incisión cutánea en la región temporal.6,10,11 En nuestro caso, ésta última es considerada la vía de elección para llevar a cabo esta intervención, puesto que evita las complicaciones de las incisiones clásicas y permite una adecuada exposición del campo quirúrgico para llevar a cabo la cirugía.

\section{Material y método}

En los últimos tres años se han intervenido en nuestro Servicio cuatro pacientes (todas de sexo femenino) para la realización

\section{Introduction}

The orbit and its contents represent an entity that is anatomically complex. The existence of certain pathologies at this level makes surgical treatment compulsory (biopsies or removal of tumors, surgical decompression of Graves-Basedow disease etc.). Choosing the most appropriate approach in view of the type of pathology and its location within the orbit, is fundamental for ensuring the success of the procedure.1,2 To date, the lateral orbitotomy is considered the ideal technique for reaching lesions in the lateral half of the orbit, for biopsies of the optic nerve and for the removal of lacrimal glands. $1,3,4$

Traditionally the lateral wall of the orbit was reached with a skin incision into the external canthal area or into the upper eyelid crease. Since the procedure was first description by Krönlein in 1888 and up until the present time, the incisions have undergone many modifications (Fig. 1).

Krönlein's original incision is along a convex curve anterior to the lateral orbital rim area. In 1960, Stallard and Wright popularized their italic "s» shape incision that ran parallel to the external orbital rim from the end of the brow, finally running parallel to the zygomatic arch. This approach route has been widely used by most surgeons up until the appearance of the eyelid incision. This is a modification of the Stallard-Wright incision, as it runs along the upper eyelid crease. It has now displaced its predecessor and it is currently considered by many authors as the incision of choice for the lateral orbitotomy. ${ }^{5}$

Although the results obtained with this incision can be considered satisfactory in most cases, it is not exempt of potential complications such as visible scars, lesions of the elevator eyelid muscle and eyelid retraction. ${ }^{6}$

In order to avoid these complications, different approaches have recently been proposed in craniofacial surgery for carrying out the lateral orbitotomy. ${ }^{7}$ The most important are the coronal 7,8 and temporozigomatic approaches, ${ }^{9}$ and the approach used for the postero-lateral orbitotomy which entails a skin incision at the temple. $6,10,11$ In this case of ours, this last approach was considered the route of choice for carrying out the intervention, as the complications that arise with the classical incisions could be avoided. Also, it allows proper exposure of the surgical field, enabling the surgery to be carried out. 
Tabla 1. Pacientes y resultados

\begin{tabular}{|c|c|c|c|c|c|c|}
\hline Caso & Sexo & Edad & $\begin{array}{l}\text { Diagnóstico clínico } \\
\text { y radiológico }\end{array}$ & $\begin{array}{c}\text { Diagnóstico } \\
\text { histopatológico }\end{array}$ & $\begin{array}{c}\text { Resultado estético } \\
\text { y funcional }\end{array}$ & Complicaciones \\
\hline 1 & Mujer & 41 & Pseudotumor & Pseudotumor & Bueno & $\begin{array}{l}\text { Paresia recto lateral. } \\
\text { Paresia rama frontal del facial }\end{array}$ \\
\hline 2 & Mujer & 29 & Linfoma & Dacrioadenitis crónica & Bueno & Paresia recto superior \\
\hline 3 & Mujer & 37 & Pseudotumor & Pseudotumor & Bueno & Paresia recto lateral \\
\hline 4 & Mujer & 53 & Pseudotumor & Pseudotumor & Bueno & Paresia recto lateral \\
\hline
\end{tabular}

Table 1. Patients and results

\begin{tabular}{|c|c|c|c|c|c|c|}
\hline Case & Sex & Age & $\begin{array}{l}\text { Clinical and } \\
\text { radiological diagnosis }\end{array}$ & $\begin{array}{c}\text { Diagnosis } \\
\text { histopathologic }\end{array}$ & $\begin{array}{l}\text { Aesthetic and functional } \\
\text { result }\end{array}$ & Complications \\
\hline 1 & Female & 41 & Pseudotumor & Pseudotumor & Good & $\begin{array}{l}\text { Lateral rectus paresis } \\
\text { Frontal branch paresis }\end{array}$ \\
\hline 2 & Female & 29 & Lymphoma & Chronic dacryoadenitis & Good & Superior rectus paresis \\
\hline 3 & Female & 37 & Pseudotumor & Pseudotumor & Good & Lateral rectus paresis \\
\hline 4 & Female & 53 & Pseudotumor & Pseudotumor & Good & Lateral rectus paresis \\
\hline
\end{tabular}

de orbitotomía lateral mediante la incisión en la zona temporal (Tabla 1).

Las cuatro pacientes habían debutado con una clínica similar de exoftalmos y diplopia de instauración progresiva y rápida, sin otros síntomas asociados; fueron valoradas en un primer momento por el Servicio de Oftalmología. En todos los casos se realizaron pruebas de imagen (RM y/o TC) como parte del estudio diagnóstico. En tres de los casos el diagnóstico radiológico de sospecha era de pseudotumor orbitario. En el cuarto caso se apreciaba una tumoración extraconal que afectaba a la parte supero-externa de la órbita, compatible radiológicamente con linfoma.

Los tres casos diagnosticados de pseudotumor fueron tratados con corticoides sistémicos según el protocolo del Servicio de Oftalmología, sin obtenerse respuesta adecuada a los mismos, por lo que se les remitió a nuestro Servicio para realización de biopsia. El caso compatible con linfoma se remitió para confirmación del diagnóstico mediante biopsia sin realizarse ningún tratamiento previo.

En los cuatro casos, el tamaño y la localización de las masas hacían recomendable el uso de la orbitotomía lateral como técnica para la toma de biopsia.

\section{Técnica quirúrgica}

La incisión empleada en nuestro caso para realizar la orbitotomía lateral es muy semejante a la usada para tallar un colgajo temporal.

Rasurar el pelo de la zona temporal y de la patilla e infiltrar la piel de dicha región con una mezcla de anestésico y vasoconstrictor (en nuestro caso lidocaína con adrenalina a concentración de $1: 100.000$ ) son medidas previas a la cirugía que si bien no son imprescindibles, facilitan la misma de forma importante.

La incisión sigue una trayectoria curvilínea de convexidad superior, dos centímetros por encima de la línea temporal superior, y con una prolongación vertical en la región preauricular hasta la raíz del hélix (Fig. 2). Esta prolongación se puede extender hacia inferior si es necesario, con el fin de permitir mayor exposición del

\section{Material and method}

Over the last three years four patients underwent surgical procedures (all female) and lateral orbitotomies were carried out by means of an incision into the temple area (Table 1).

All four patients had initially displayed similar clinical symptoms such as exophthalmos and diplopia with an onset that was both progressive and rapid, and which had no associated symptoms. They were first evaluated by the Ophthalmology Department. In all cases imaging studies were carried out (MRI and/or CAT) as part of the diagnostic study. In three of the cases the suspected radiological diagnosis was of orbital pseudotumor. In the fourth case, an extraconal tumor-like mass could be appreciated that was affecting the supero-external part of the orbit. It was consistent radiologically with a lymphoma.

The three cases with a diagnosis of pseudotumor were treated with systemic corticoids according to the Ophthalmology Department protocol. As the response proved inadequate, they were referred to our department for biopsy. The case that was compatible with lymphoma was referred to us for diagnostic confirmation by biopsy without previous treatment.

In all four cases the size and location of the mass made using the lateral orbitotomy advisable as a biopsy technique.

\section{Surgical technique}

The incision used for carrying out the lateral orbitotomy in this particular case is very similar to that used for harvesting the temporalis flap.

The head is shaved in the temple and sideburn area and the skin in this area is infiltrated with an anesthesia-vasoconstrictor mixture (in our case lidocaine with adrenalin at a concentration of 1:100.000) these are steps previous to 
campo quirúrgico. En su diseño, la incisión suele quedar en su mayor parte por detrás de la línea de inserción del pelo, lo que permite que quede oculta por el mismo. En su parte anterior no es necesario prolongarla en exceso, para evitar dejar cicatrices en la región frontal y para no lesionar la rama frontal del nervio facial, que discurre a un centímetro y medio por detrás del reborde orbitario. ${ }^{12}$

La incisión profundiza en su parte posterior hasta llegar a la fascia temporal profunda. Desde aquí la disección se continúa hacia delante por encima de dicha fascia, lo que evita lesionar la rama frontal del facial, que queda incluida en el tejido celular subcutáneo y la fascia temporoparietal. 13,12 Se progresa de esta forma hasta alcanzar el marco orbitario lateral y superior (Fig. 3). A partir de este punto la técnica es la misma que la empleada en cualquier orbitotomía lateral independientemente de la incisión cutánea empleada.

El periostio se corta aproximadamente dos milímetros por detrás del reborde orbitario lateral. El músculo temporal se rechaza en sentido posterior, desinsertándolo de la fosa temporal y exponiendo así la parte externa de la pared lateral de la órbita. El periostio también se debe despegar cuidadosamente en la parte interna de la órbita.

Previamente a realizar las osteotomías se debe planificar la reposición del fragmento óseo que retiramos para acceder al contenido intraorbitario. Para ello se marcan los cortes óseos con un lápiz estéril de grafito, se preforma una miniplaca de titanio de bajo perfil y se hacen los orificios para los tornillos en el marco orbitario lateral, teniendo precaución de dejar al menos dos tornillos a cada lado de las marcas realizadas.

A continuación se protege en contenido orbitario colocando suavemente una valva maleable en la cara interna de la órbita, entre hueso y periostio. El corte superior se realiza a nivel de la sutura frontocigomática o sobre ella. El inferior, en la unión del arco cigomático y del reborde orbitario lateral. Las osteotomías se realizan con una sierra oscilante y deben tener una dirección confluente, hasta confluir en un punto situado aproximadamente un centímetro y medio por detrás del reborde orbitario, sobre el ala

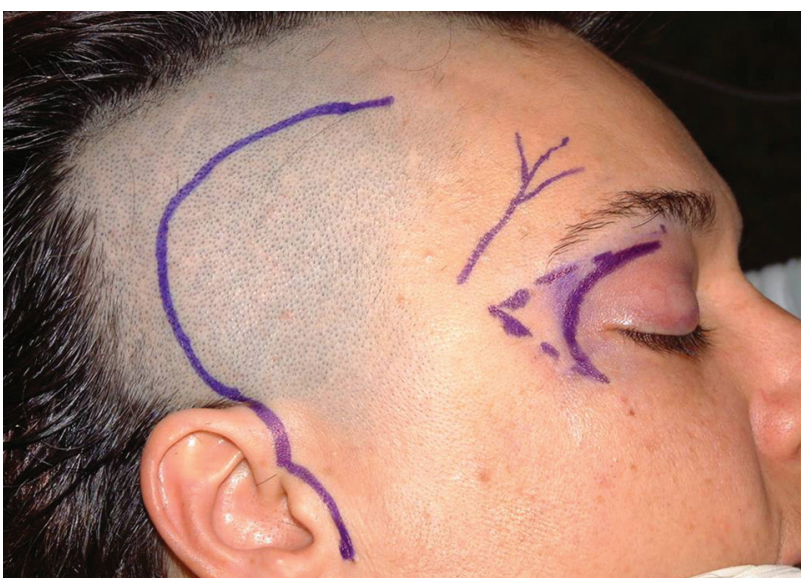

Figura 2. Diseño de la incisión temporal.

Figure 2. Design of temporal incision.
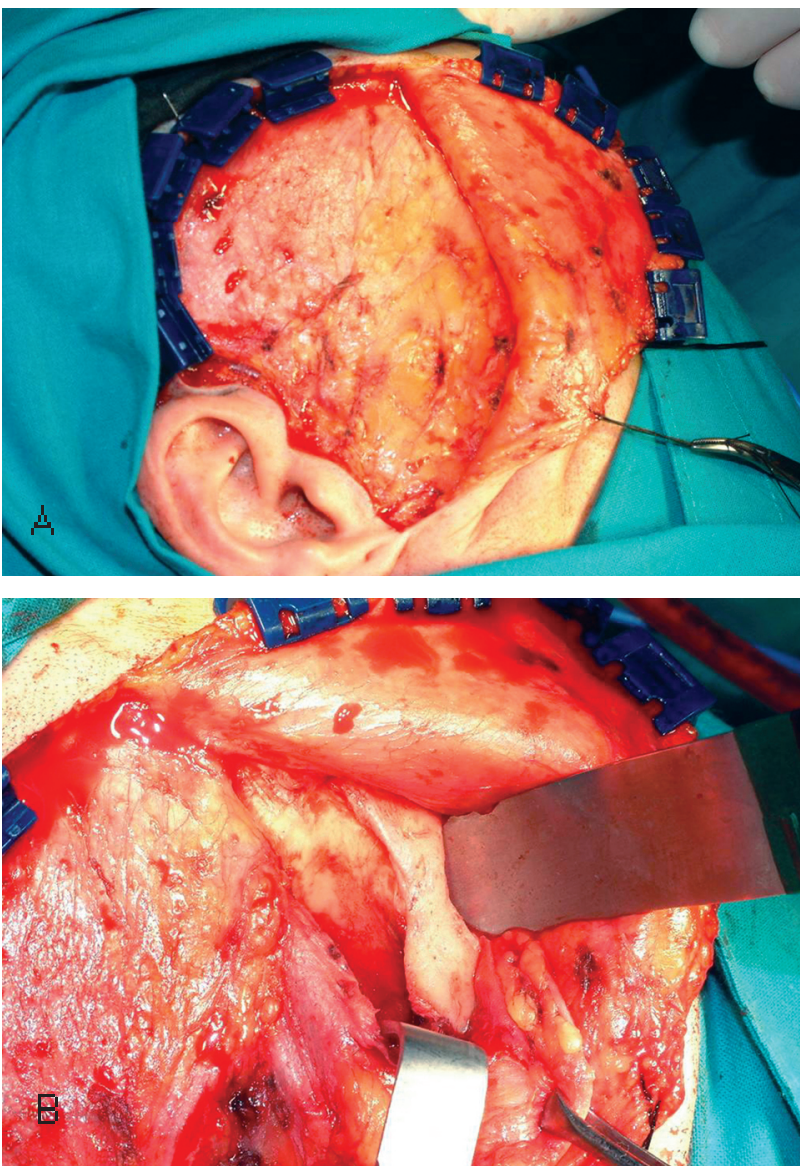

Figura 3. A) Disección entre la fascia temporal profunda y la fascia temporoparietal. B) Exposición de la pared lateral de la órbita. Figure 3. A) Dissection between the deep temporal fascia and the temporoparietal fascia. B) Exposure of the lateral wall of the orbit. the surgery that, although not essential, facilitate the latter considerably.

A curvilinear incision is made with a superior convex curve, two centimeters above the superior temporal line, and with a vertical extension in the preauricular region to the tail of the helix (Fig. 2). This vertical extension can be continued downwards if necessary, for greater exposure of the surgical field. Most of the incision line is designed so that it is behind the hair line, which means that it is hidden. Extending the anterior part of the incision line very far is not necessary as scarring in the frontal region should be avoided and care should be taken not to damage the frontal branch of the facial nerve that runs a centimeter and half behind the orbital rim. ${ }^{12}$

The posterior part of the incision is deepened to the deep layer of the temporal fascia. From this point the dissection continues forwards over the fascia, so that the frontal branch of the facial nerve that is within the subcutaneous cellular tissue and the temporoparietal fascia is not damaged. ${ }^{13,12}$ The lateral and superior orbital rims are then accessed (Fig. 3). From this point the technique is the same as that used in any lateral orbitotomy regardless of the skin incision used.

The periosteum is cut approximately two millimeters behind the lateral orbital rim. The temporalis muscle is retracted posteriorly, it is disinserted from the temporal fossa, and the external part of the lateral wall of the orbit is exposed. The periosteum in the internal part of the orbit should also be stripped carefully. 
mayor del esfenoides. El fragmento de hueso así eliminado tiene forma triangular de vértice posterior (Fig. 4).

Si hace falta, las osteotomías se pueden completar con un escoplo fino. Visualizar la parte interna de la órbita ayuda a controlar adecuadamente dónde se realizan los cortes del hueso, lo cual es especialmente importante para evitar entrar en la fosa craneal anterior al realizar el superior.

Tras retirar el fragmento óseo, se incide la periórbita y se accede al contenido intraorbitario mediante disección de la grasa periocular y movilización del músculo recto lateral del ojo si es necesario.

Después del procedimiento intraorbitario se recoloca la pared ósea mediante la miniplaca de bajo perfil y se cierra la incisión por planos (perios-

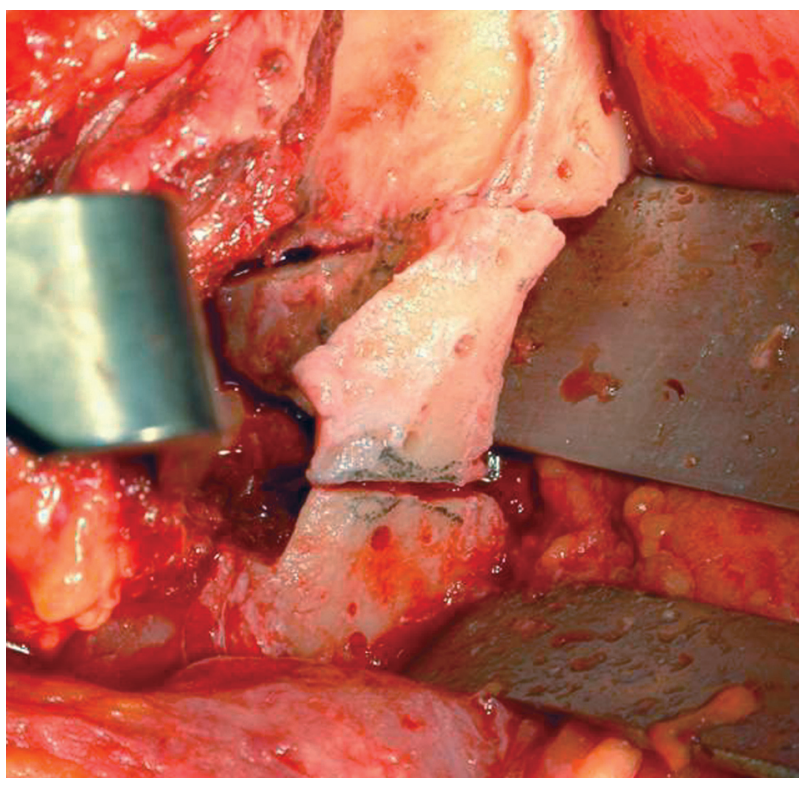

Figura 4. Osteotomías.

Figure 4. Osteotomies.
Before carrying out the osteotomies, repositioning the bone fragment that is to be removed for accessing the intraorbital contents, should be planned. For this the bone incisions that are to be made are marked with a sterile graphite pencil, and the lowprofile titanium miniplate is first shaped and the holes for the screws are made in the lateral orbital wall, taking care that at least two screws are left at each side of the marks made.

Next, the contents of the orbit are protected by gently placing a malleable valve on the inside of the orbit, between the bone and the periosteum.

The upper incision is carried y piel). Es recomendable dejar un drenaje en el espacio subcutáneo durante las primeras 24-48 horas para evitar hematomas posquirúrgicos.

\section{Caso clínico}

Paciente de 29 años que fue valorada en el Servicio de Oftalmología por proptosis axial del ojo izquerdo y diplopia de reciente aparición (aproximadamente un mes) y progresión rápida. Se le realizó RMN en la que se evidenció la existencia de una masa extraconal en la región súpero-externa de la órbita izquierda con características radiológicas de linfoma (Fig. 5).

Por las características y localización de la masa, la orbitotomía lateral se consideró la vía de abordaje ideal para su biopsia-extirpación. Se realizó la técnica mediante una incisión en la zona temporal, encontrándose en el acto intraoperatorio una masa bien delimitada y encapsulada, que se pudo extirpar por completo. El resultado anatomopatológico de la pieza fue de dacrioadenitis crónica.

Los resultados estéticos y funcionales obtenidos fueron excelentes, apareciendo como única complicación la paresia de los músculos recto superior y lateral del ojo izquierdo, que desapareció espontáneamente al cabo de dos meses. Seis meses después de la intervención, no se han presentado complicaciones de ningún tipo.

\section{Resultados}

En los cuatro casos el abordaje temporal permitió llevar a cabo adecuadamente la orbitotomía lateral y el acceso a las lesiones intraorbitarias. En tres casos se encontraron masas mal definidas que se biopsiaron. En el caso diagnosticado radiológicamente como linfoma, se encontró una masa encapsulada y bien delimitada que pudo out on a level with the frontozygomatic suture or above it. The lower one is made where the zygomatic arch and the lateral orbital rim join. The osteotomies are carried out with an oscillating saw and in the direction of a point approximately a centimeter and a half behind the orbital rim, over the greater wing of the sphenoid bone. The posterior vertex of the bone fragment that has been removed will therefore have a triangular shape (Fig. 4).

If necessary, the osteotomies can be completed with a fine chisel. Examining the inside of the orbit helps to control properly where the cuts into the bone are made, which is especially important when trying to avoid entering the anterior cranial fossa on performing the upper cut.

After removing the bone fragment, the periorbita is incised and the intraorbital content is reached by means of dissecting the periocular fat and moving the lateral rectus muscle away from the eye if necessary.

After the intraorbital procedure, the bony wall is replaced using the low-profile miniplate and the incision is closed by layers (periosteum, temporo-parietal fascia, subcutaneous layer and skin). For the first 24-28 hours leaving a subcutaneous drain is advisable so that postsurgical hematomas are avoided.

\section{Case Report}

Patient, 29 years old, was evaluated by the Ophthalmology Department due to axial proptosis of the left eye and diplopia that had only recently appeared (one month approximately) and that was progressing rapidly. MRI was carried out which showed the existence of an extraconal mass in the supero-external region of the left orbit which appeared radiologically to be a lymphoma (Fig. 4). 

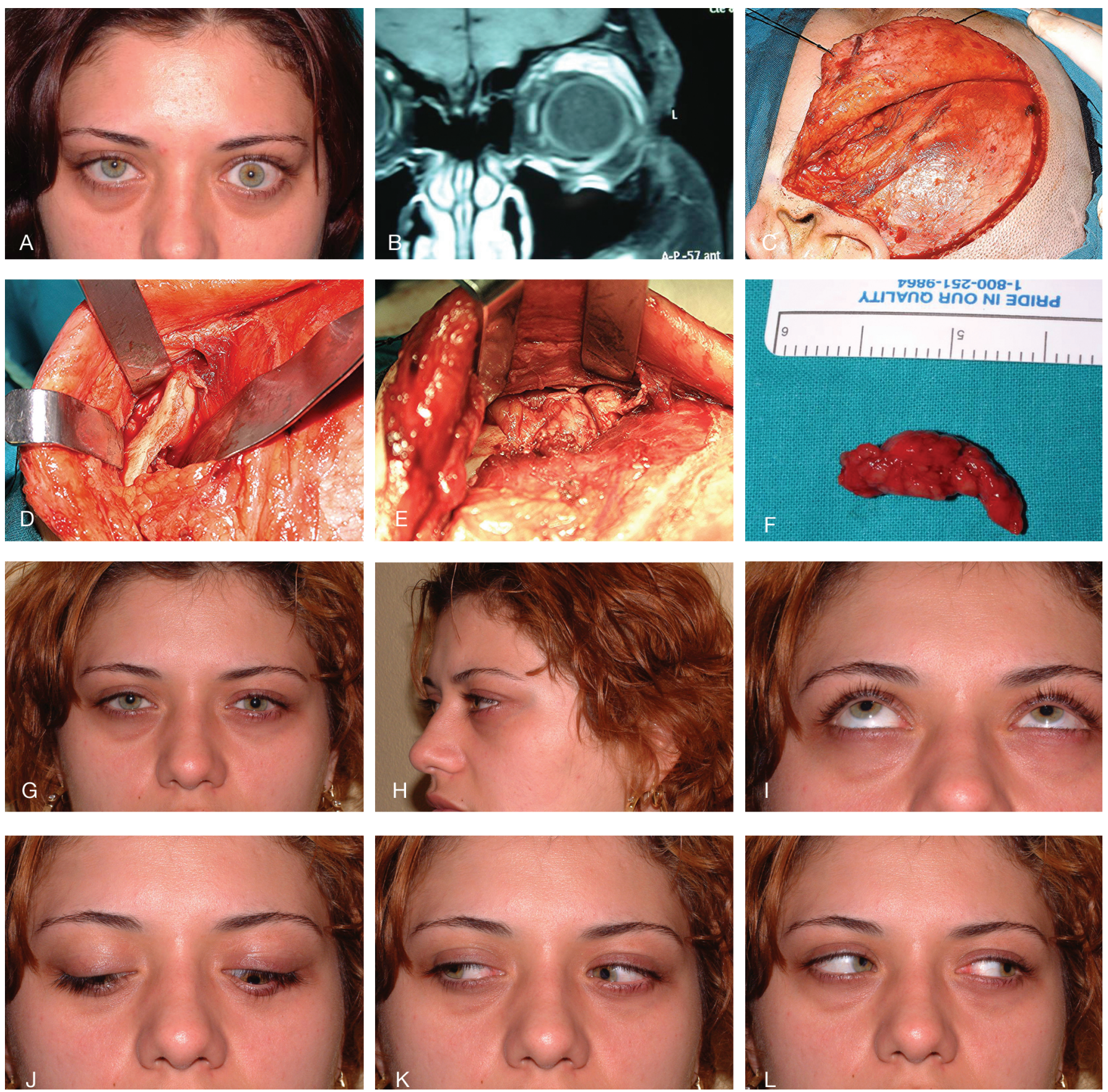

Figura 5. A) Estado preoperatorio. Se puede apreciar la importante proptosis del ojo izquierdo. B) Imagen de RM. Tumor extraconal superoexterno de la órbita izquierda. C) Disección de la región temporal. D) Exposición de la pared lateral de la órbita. E) Tumoración correspondiente a la glándula lacrimal afectada por dacrioadenitis crónica. F) Pieza quirúrgica. G y H) Resultado estético a los seis meses de la cirugía. I-L) Resultado funcional a los seis meses de la cirugía.

Figure 5. A) Preoperative state. The considerable proptosis of the left eye can be appreciated. B) MRI image. Supero-external extraconal tumor of the left orbit. C) Temporal region dissection. D) Exposure of the lateral wall of the orbit. E) Tumor-like mass as a result of the lacrimal gland that is affected by chronic dacryoadenitis. F) Surgical specimen. $G$ y H) Aesthetic result six months after surgery. I-L) Functional result six months after surgery.

ser extirpada completamente. El análisis anatomopatológico confirmó el diagnóstico de pseudotumor orbitario en los tres casos con esa sospecha. En el caso de posible linfoma, el diagnóstico definitivo fue de dacrioadenitis crónica, correspondiendo la masa extirpada a la glándula lacrimal alterada por fenómenos inflamatorios.
Given the characteristics and location of the mass, a lateral orbitotomy was considered as the best route for the biopsy-excision. The technique was carried out by means of an incision into the temple, and during the surgical procedure a well-defined, encapsulated mass was found that could 
Las pacientes con diagnóstico definitivo de pseudotumor orbitario fueron remitidas de nuevo al Servicio de Oftalmología para continuar con el tratamiento de su proceso (corticoterapia sistémica a más altas dosis que las administradas con anterioridad).

En todos los casos se obtuvo un resultado estético excelente. La cicatriz resultante de la intervención quedó completamente oculta por el cabello, sin secuela visible de ningún tipo. Obviamente, este abordaje evita cualquier fenómeno de retracción palpebral debido a la vía de acceso (Fig. 6).

En todos los casos se produjo una paresia transitoria del músculo recto lateral y/o superior del ojo (derivada de la manipulación intraocular, no de la vía de abordaje en sí misma).

La única complicación achacable directamente a este abordaje fue la aparición en una de las pacientes de paresia transitoria de la rama frontal del nervio facial.

Hasta la fecha no se ha presentado ninguna complicación permanente ni a largo plazo en ninguna de las pacientes.

\section{Discusión}

La cirugía orbitaria suele conllevar un alto grado de dificultad, debido a la existencia de gran número de estructuras nobles en un espacio físicamente reducido y con relaciones anatómicas complejas. Quizá debido a esta complejidad no existe una única técnica «ideal» para el acceso a la órbita, necesitando el empleo de diferentes procedimientos en función al tipo de patología y el tamaño, número y localización de las lesiones.

Aunque continuamente aparecen nuevas formas de acceder al interior de la órbita (destacando la endoscopia, cada vez más ampliamente utilizada), ${ }^{14}$ la orbitotomía lateral sigue siendo la técnica de elección según la mayoría de los autores para la extirpación (y hasta el momento también para la biopsia) de lesiones laterales al nervio óptico (tanto intra como extraconales) y de la glándula lacrimal. Esta cirugía conlleva el acceso a la pared lateral de la órbita y la remoción de un fragmento de la misma mediante osteotomías para poder alcanzar el contenido intraorbitario.

El procedimiento ha sufrido múltiples modificaciones desde su primera descripción por Krönlein, con el fin de disminuir las potenciales secuelas estéticas y funcionales para el paciente. ${ }^{15}$ Estas modificaciones han consistido por lo general en cambios en las incisiones cutáneas para el acceso a la pared lateral de la órbita, buscando cada vez cicatrices más «estéticas». Por el contrario, la forma de realizar las osteotomías se ha mantenido prácticamente igual respecto a la descripción original, aunque algunos autores han introducido variaciones, con el fin de facilitar a la hora del cierre la reposición del fragmento óseo retirado para acceder al interior de la órbita. ${ }^{16}$ be completely removed. The anatomopathologic diagnosis of the specimen was of chronic dacryoadenitis.

The aesthetic and functional results were excellent, with the only complication being paresthesia of the upper and lateral rectus muscles of the left eye, that disappeared spontaneously after two months. Six months after the surgery, no complications of any type have arisen.

\section{Results}

In all four cases the temporal approach proved adequate for carrying out the lateral orbitotomies and for accessing the intraorbital lesions. In three cases the masses that were found were not well-defined and a biopsy was performed. In the case that was diagnosed radiologically as a lymphoma, a well-defined encapsulated mass was found that could be removed completely. The anatomopathologic analysis confirmed the diagnosis of orbital pseudotumor in the three cases with this suspicion. In the cases of possible lymphoma, the definitive diagnosis was of chronic dacryoadenitis and the mass removed was actually from the lacrimal gland that had been affected by inflammatory phenomena.

The patients with the definitive diagnosis of pseudotumor of the orbit were sent back to the Ophthalmology Department to continue treatment (systemic corticotherapy at a higher dosage than had been given previously).

The aesthetic result was excellent in all cases. The surgical scar was completely covered by hair and there were no visible sequelae of any type. Obviously, this approach avoids any incidence of eyelid retraction given the access route chosen (Fig. 6).

In all cases transitory paresthesia was produced of the lateral and upper rectus muscles of the eye (as a result of intraocular manipulation, not the access route itself).

The only complication that could be directly attributed to this approach was the appearance in one of the patients of transitory paresthesia in the frontal branch of the facial nerve.

To date there have not been any permanent or long term complications in any of the patients.

\section{Discussion}

Surgery of the orbit tends to carry a high degree of difficulty due to the existence of a large numbers of important structures in a physically small space and with complex 
La incisión ideal para abordar la pared lateral de la órbita debería evitar lo máximo posible las complicaciones y secuelas en el paciente y permitir un acceso cómodo y suficientemente amplio al campo quirúrgico. Durante los últimos años la incisión más utilizada para realizar la orbitotomía lateral, ha sido la palpebral superior. Aunque los resultados que se obtienen con ella son por lo general aceptables y permite un adecuado acceso a la pared lateral de la órbita, no está exenta de potenciales complicaciones, ya que, aunque mínimamente, es necesario seccionar el músculo orbicular y los vasos linfáticos del párpado. Debido a esto, secundariamente a la cirugía puede aparecer retracción palpebral, lesión del músculo elevador del párpado con la consiguiente dificultad para la apertura ocular o edema palpebral permanente. Además, a pesar de quedar camuflada en un pliegue del párpado, no se puede considerar que la cicatriz sea completamente invisible.

Como alternativas a esta incisión, y en ocasiones de la mano de la cirugía craneofacial, han ido surgiendo otras que intentan evitar sus inconvenientes. Una de las más versátiles es la incisión en la zona temporal. Además de aportar una exposición excelente del campo quirúrgico, y facilitar en gran medida la intervención, presenta dos grandes ventajas: la cicatriz que provoca queda prácticamente por completo oculta por el pelo y no obliga a realizar ninguna manipulación sobre el párpado, evitando las secuelas que pueden quedar a este nivel al emplear otras vías de abordaje. Además, el plano quirúrgico entre la fascia temporal profunda y la temporoparietal es prácticamente avascular, lo que hace que la técnica quirúrgica sea relativamente sencilla en la mayoría de los casos.

Como principal inconveniente, se le puede achacar a este abordaje la posibilidad de lesionar la rama frontal del nervio facial. Si se respetan los planos quirúrgicos y se tiene cierto cuidado a la hora de realizar la disección, esta complicación es muy infrecuente. Por otra parte, suele deberse a fenómenos de tracción y compresión sobre el nervio al separar o realizar la disección, y no a lesión directa del nervio, por lo que cuando aparece, suele ser en forma parcial (paresia y no parálisis), y la norma es la recuperación completa y espontánea en la mayoría de los casos.

\section{Conclusiones}

La técnica aquí descrita es posiblemente una de las más adecuadas para realizar una orbitotomía lateral. La incisión temporal supera en muchas ocasiones a las incisiones clásicas, obtiene resultados estéticos y funcionales excelentes, supone mínima morbilidad para el paciente y es técnicamente sencilla en la mayoría de los casos. Por esto es perfectamente recomendable como alternativa a otras incisiones, incluyendo la palpebral superior, que en los últimos tiempos ha sido la de elección para la mayoría de los autores.

\section{Agradecimientos}

Queremos agradecer a la Dra. Alejandra Rojas su colaboración desinteresada en la realización de este trabajo. anatomic relationships. Perhaps it is because of this complexity that there is no single technique that is «ideal» for reaching the orbit, and different procedures are needed according to the type of pathology and the size, number and location of the lesions.

Although new ways of reaching the interior of the orbit are continually appearing (with endoscopy standing out as it is increasingly used),${ }^{14}$ the lateral orbitotomy is still the technique of choice according to most authors for excision (and currently for biopsies) of lesions that are lateral to the optic nerve (intraconal as well as extraconal) and of the lacrimal gland. This surgery requires accessing the lateral wall of the orbit and removing a fragment by means of an osteotomy so that the contents of the orbit can be reached.

The procedure has undergone many modifications since it was first described by Krönlein, so that the potential aesthetic and functional sequelae can be reduced for the patient. ${ }^{15}$ These modifications consist generally in changes in the skin incisions for accessing the lateral wall of the orbit, as scars that are more "aesthetic» are sought. The way osteotomies are carried out has, on the other hand, been kept practically the same with regard to the original description, although some authors have introduced variations, so that closure and replacing the bone fragment removed when gaining access to the interior of the orbit is made eariser..$^{16}$

The ideal incision for approaching the lateral wall of the orbit should avoid any complications and sequelae for the patient as much as possible, and the access to the surgical field should be wide enough to allow the area to be reached with ease. Over the last years the incision most used for carrying out a lateral orbitotomy has been the upper eyelid approach. Although the results obtained are generally acceptable, and adequate access to the lateral wall of the orbit is facilitated, it is not exempt of potential complications, as the orbicular muscle has to be sectioned at least minimally together with the lymphatic vessels of the eye lid. As a result of this, eyelid retraction can appear secondary to surgery together with lesions of the lid elevator muscle. Lid opening may be difficult and there may be permanent eyelid edema. In addition to this, despite being camouflaged in the eyelid crease, it cannot be claimed that the scar is completely invisible.

Other approaches have appeared, some in conjunction with craniofacial surgery, that try to avoid these inconveniences by using alternative incisions. One of the most versatile is the temple incision. In addition to providing excellent surgical field exposure and facilitating to a large extent the intervention, it has two great advantages: the scar is nearly completely hidden by hair and the eyelid does not have to be touched. The sequelae that may remain in this area from using other approach routes are in this way avoided. The surgical plane between the deep temporal and temporoparietal fasciae is practically avascular, which means that the surgical technique is, in most cases, relatively simple.

The chief inconvenience that can be attributed to this approach is the possibility of damaging the frontal branch 


\section{Bibliografía}

1. Nerad JA. Cirugía oculoplástica: los requisitos. En: Pellerin P, Lesoin F, Dhellemmes P, Donazzan M, Jomin M. Cap. 14. Elsevier Science 2002;387-417.

2. Schick $U$, Dott $U$, Hassler W. Surgical treatment of orbital cavernomas. Surg Neurol 2003;60:234-44.

3. Arai $H$, Sato K, Katsuta T, Rhoton AL Jr. Lateral approach to intraorbital lesions: Anatomic and surgical consideration (surgical anatomy and technique). Neurosurg 1996;39:1157-63.

4. Rothon A L Jr. The orbit. Neurosurgery 2002;51(Suppl 1):303-34.

5. Abouchadi A, Capon-Degardin N, Martinot-Duquennoy V, Pellerin P. Orbitotomie latérale par voie palpébrale supérieure. Annales de chirurgie plastique esthétique 2005;50:221-7.

6. Carta F, Siccardi D, Cossu M, Viola C, Maiello M. Removal of tumours of the orbital apex via a postero-lateral orbitotomy. J Neurosurg Sciences 1998;42: 1858.

7. Kalmann R, Mourits M Ph, van der Pol JP, Koornneef L. Coronal approach for rehabilitative orbital decompression in Graves' ophthalmopathy. Br J Ophthalmol 1997;81:41-5.

8. Tessier P. Inferior orbitotomy. A new approach to the orbital floor. Clin Plast Surg 1982;9:569-75.

9. Pellerin $P$, Lesoin $F$, Dhellemmes $P$, Donazzan $M$, Jomin M. Usefulness of the orbitofrontomalar approach associated with bone reconstruction for frontotemporosphenoid meningiomas. Neurosurgery 1984;15:715-8.

10. Cossu M, Pau A, Viale GL. Postero-lateral microsurgical approach to orbital tumors. Minim Invas Neurosurg 1995;38:129-31.

11. Viale GL, Pau A. A plea for postero-lateral orbitotomy for microsurgical removal of tumours of the orbital apex. Acta Neurochir 1998;90:124-6.

12. Urken ML. Atlas of Regional and Free Flaps of Head and Neck Reconstruction. New York 1995, Raven Press. Cap. 14, pp. 197-211.

13. Rouvière H, Delmas A. Anatomía Humana. París 1994, Masson. Tomo I, pp. 525 y sig.

14. Tsirbas A, Kazim M, Close L. Endoscopic approach to orbital apex lesions. Ophthal Plast Reconstr Surg 2005;21:271-5.

15. Harris G], Logani SC. Eyelid crease incision for lateral orbitotomy. Ophthal Plast Reconstr Surg 1999;15:9-16.

16. Hunter KLY, Chong YH, Chan SK, Tse KK, Chan N, Lam DSC. Modified lateral orbitotomy for intact removal of orbital Dumbbell dermoid cyst. Ophthal Plast Reconstr Surg 2004;20:327-9. of the facial nerve. If the surgical layers are respected, and if care is taken when carrying out the dissection, this complication is very infrequent. On the other hand, this can be due to traction phenomena and compression on the nerve on separating or carrying out the dissection, and not to the nerve being damaged directly. When this appears it tends to be partial (paresis and not paralysis), and in most cases there is normally complete and spontaneous recovery.

\section{Conclusions}

The technique we have described here is possibly one of the most adequate for carrying out a lateral orbitotomy. The temple incision very often surpasses the classical incisions, and excellent aesthetic and functional results are obtained. There is minimum morbidity for the patient and, in most cases, it is technically simple. For these reasons, it can be perfectly recommended as an alternative to other incisions, including the upper eyelid incision, that has been chosen by most authors over recent years.

\section{Acknowledgements}

We would like to thank Dr. Alejandra Rojas for her generous contribution in carrying out this work. 